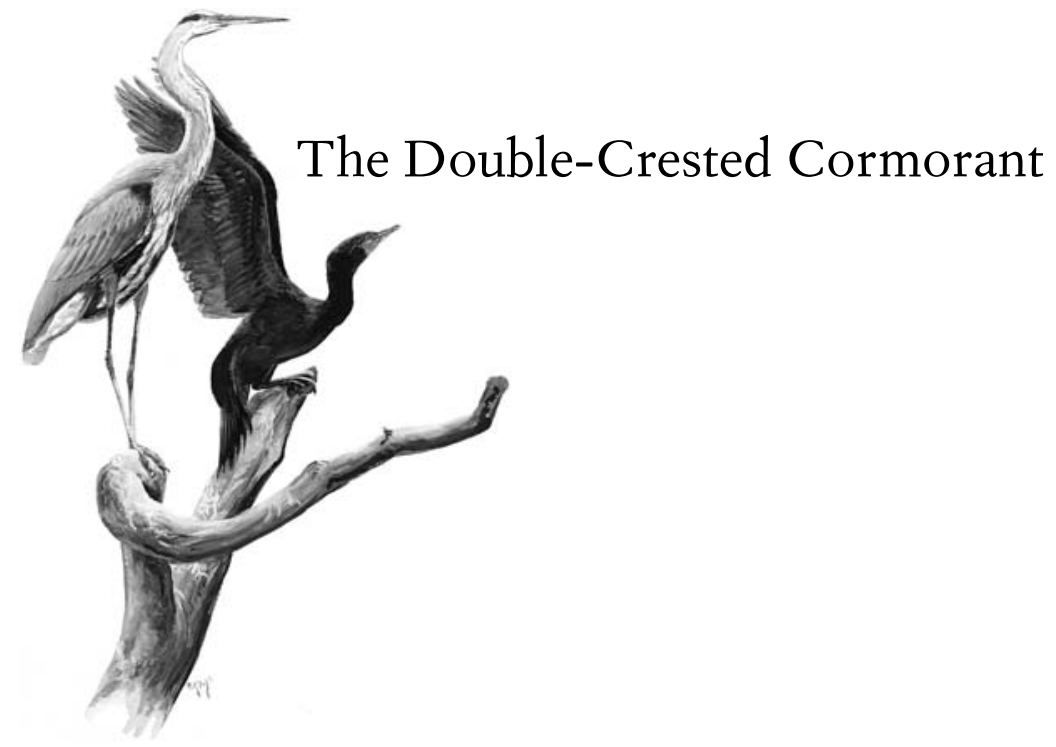




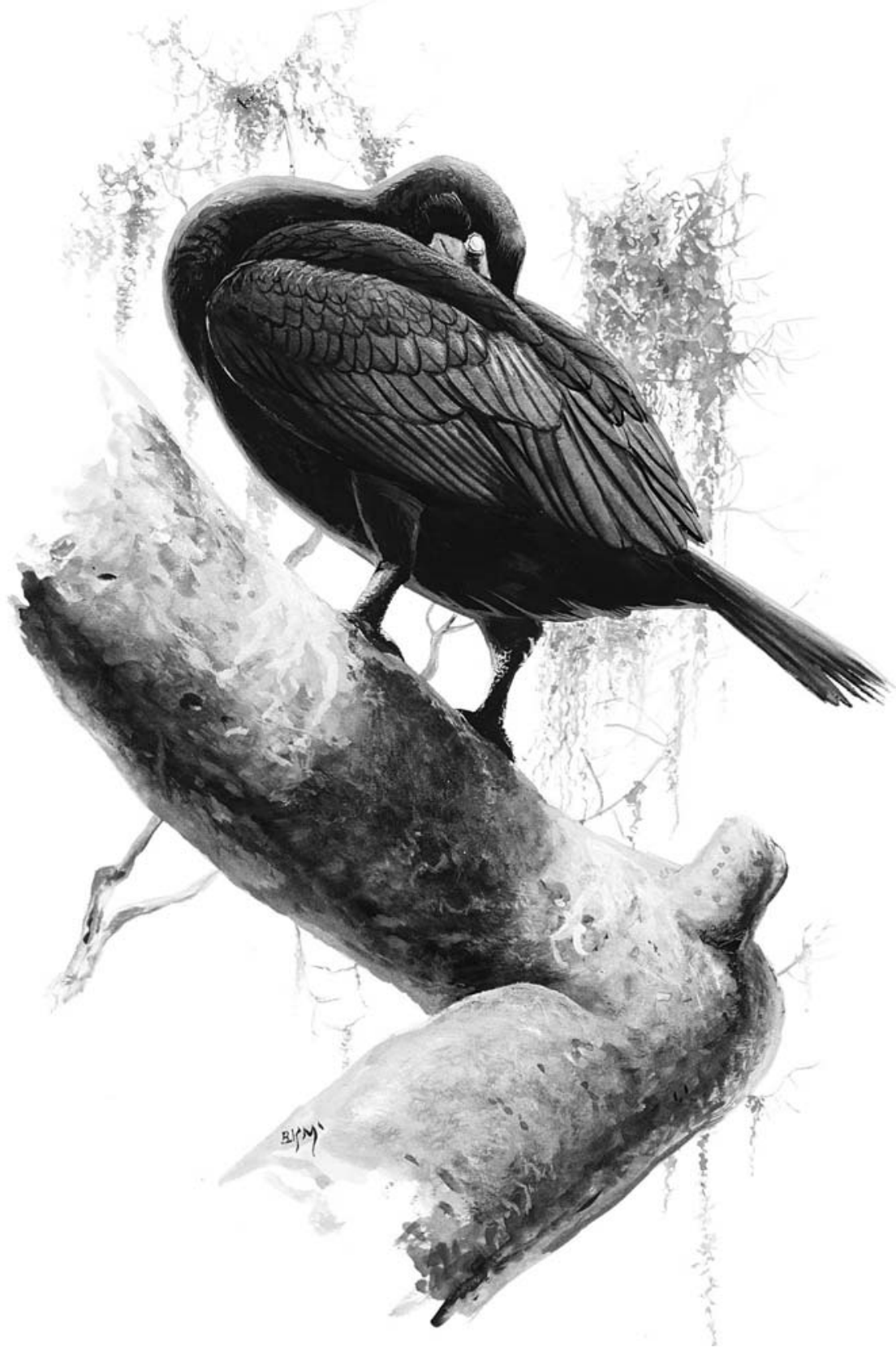




\section{The \\ Double-Crested Cormorant}

Plight of a Feathered Pariah

\section{Linda R. Wires}

With original illustrations by Barry Kent MacKay

Yale

UNIVERSITY PRESS

New Haven and London 
Published with assistance from the foundation established in memory of William McKean Brown.

Copyright (C) 2014 by Linda R. Wires.

All rights reserved.

This book may not be reproduced, in whole or in part, including illustrations, in any form (beyond that copying permitted by Sections 107 and 108 of the US Copyright Law and except by reviewers for the public press), without written permission from the publishers.

Yale University Press books may be purchased in quantity for educational, business, or promotional use. For information, please e-mail sales.press@ yale.edu (US office) or sales@yaleup.co.uk (UK office).

Designed by Sonia Shannon.

Set in Fournier type by Newgen North America.

Printed in the United States of America.

Library of Congress Control Number 2013957500

A catalogue record for this book is available from the British Library.

This paper meets the requirements of ANSI/ NISO Z39.48-1992 (Permanence of Paper). 


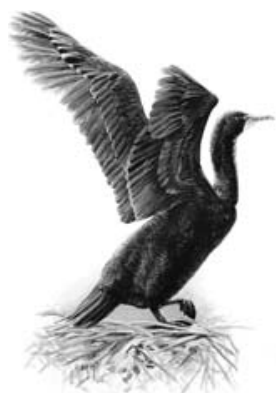

This book is for all the animals that have been misunderstood 
This page intentionally left blank 